IZA DP No. 8182

The Main Support Mechanisms to Finance Renewable Energy Development

Shahrouz Abolhosseini

Almas Heshmati

May 2014 


\title{
The Main Support Mechanisms to Finance Renewable Energy Development
}

\author{
Shahrouz Abolhosseini \\ TEMEP, Seoul National University
}

\author{
Almas Heshmati \\ Jönköping University \\ and IZA
}

Discussion Paper No. 8182
May 2014

IZA

P.O. Box 7240

53072 Bonn

Germany

Phone: +49-228-3894-0
Fax: +49-228-3894-180
E-mail: iza@iza.org

Any opinions expressed here are those of the author(s) and not those of IZA. Research published in this series may include views on policy, but the institute itself takes no institutional policy positions. The IZA research network is committed to the IZA Guiding Principles of Research Integrity.

The Institute for the Study of Labor (IZA) in Bonn is a local and virtual international research center and a place of communication between science, politics and business. IZA is an independent nonprofit organization supported by Deutsche Post Foundation. The center is associated with the University of Bonn and offers a stimulating research environment through its international network, workshops and conferences, data service, project support, research visits and doctoral program. IZA engages in (i) original and internationally competitive research in all fields of labor economics, (ii) development of policy concepts, and (iii) dissemination of research results and concepts to the interested public.

IZA Discussion Papers often represent preliminary work and are circulated to encourage discussion. Citation of such a paper should account for its provisional character. A revised version may be available directly from the author. 


\title{
ABSTRACT \\ The Main Support Mechanisms to Finance Renewable Energy Development
}

\begin{abstract}
Considering that the major part of greenhouse gases is carbon dioxide, there is a global concern aimed at reducing carbon emissions. Additionally, major consumer countries are looking for alternative sources of energy to avoid the impact of higher fossil fuel prices and political instability in the major energy supplying countries. In this regard, different policies could be applied to reduce carbon emissions, such as enhancing renewable energy deployment and encouraging technological innovation and creation of green jobs. There are three main support mechanisms employed by governments to finance renewable energy development programs: feed-in-tariffs, tax incentives, and tradable green certificates. Considering that many of the promising technologies to deploy renewable energy require investment in small-scale energy production systems, these mechanisms could be used to enhance renewable energy development at the desired scale. Employing a carbon emission tax or emission trading mechanism could be considered ideal policies to mitigate emissions at the lowest cost. The comparison of feed-in-tariffs and renewable portfolio standard policies showed that the former is good when a policy to develop renewable energy sources with a low level of risk for investors is considered. However, the latter is an appropriate policy when a market view policy is applied by the government.
\end{abstract}

JEL Classification: H23, L71, O13, O31, Q27, Q42

Keywords: renewable energy, financing renewable energy, feed-in-tariffs, tax incentives, tradable green certificates, carbon emission tax, green jobs

Corresponding author:

Almas Heshmati

Department of Economics

Jönköping University

P.O. Box 1026

55111 Jönköping

Sweden

E-mail: almas.heshmati@gmail.com 


\section{Introduction}

Electricity consumption is predicted to comprise an increasing share of the global demand for energy over the next two decades. This is explained by the importance of electricity to industries. It is expected that the growth rate of electricity consumption will be more than that of the consumption of the other sources of energy, including liquid fuels, natural gas, and coal (IEA, 2012a). Due to ongoing concerns regarding climate change, the increasing price of fossil fuels, and political instability in major energy supplying countries, renewable energy (RE) sources have become an important topic of research in world energy demand.

Green economy is also considered as a source of job creation. Gai et al. (2011) investigates whether the relationship between green economy and green jobs is a myth or reality. This paper analyzes the direct and indirect employment impacts of two main greenhouse gas mitigation policies on the power generation sector in China. Promoting the corporate social responsibility for a green economy and innovative jobs are among areas of interest with potential to be developed. Pop et al. (2011) analyzes the role of social capital and promoting active aging in order to assure corporate social responsibility at national and international levels. In another study Edwards et al. (2013) studies investing in nature by analyzing restoring coastal habitat blue infrastructure and green job creation. Yi (2013) investigates clean energy policies and green jobs by evaluating green jobs in U.S. metropolitan areas.

The economic view is an essential part of renewable energy deployment and its progress. If they do not have an economic advantage, renewable energy technologies will not be able to compete with the conventional resource technologies. On the other hand, it is difficult to establish a transparent figure for the unit cost of renewable energy compared to conventional sources. External costs, such as the social and environmental costs, are included in the discussion of conventional sources. Additionally, the subsidies paid for the consumption of fossil fuels act as a barrier for alternative sources, making it more expensive for these sources to compete. The aim of increasing the contribution of renewable energy to the total energy supply is of worldwide importance in mitigating the negative energy effects of climate change.

In reality, there is a gap between the actual share and optimal level of renewable energy consumptions in the world. Furthermore, a large amount of investment is spent on conventional energy sources compared to renewable energy sources. Alternative policies for environmental protection are applied in the form of economic incentives and non-incentive regulations. Examples of economic policies include incentives for using renewable energy and imposing taxes on emission generation or fossil fuel consumption. Although developed countries that import crude oil have imposed carbon taxes for many years, these taxes have not been applied for environmental purposes.

Three types of support mechanisms are widely used: feed-in-tariffs, tax incentives, and tradable green certificates. We do not consider direct supports paid to producers or consumers, because our purpose is to apply a mechanism to encourage the creation of a renewable energy market. Direct financial transfer may lead to the enhancement of renewable energy consumption, but the main target (i.e., market creation) is not achieved. Generally, different kinds of economic instruments, such as capital grants, grants to infrastructure, utility procurement, etc., are available for renewable energy technologies. However, most of them are not appropriate for electricity produced by individually distributed generators. Considering that many of the most promising technologies to deploy renewable energy to achieve targets for energy efficiency or carbon reduction require investment in small-scale energy production systems (such as residential building), these mechanisms could be used to enhance renewable energy development to the desired scale. In particular, they will be 
applicable to the renewable energy market, which is constituted by a large number of individual energy suppliers.

The rapid growth of renewable energy has been possible through decreasing technology costs, increasing fossil-fuel prices, and the continued payment of subsidies by the state. According to an IEA report in 2012, the subsidies are estimated to increase from $\$ 88$ billion in 2011 to almost \$240 billion in 2035 (IEA, 2012b). On the other hand, fossil-fuel consumption subsidies were estimated at $\$ 523$ billion in 2011, nearly six times more than the financial support allocated to renewable energy. This means that the support given to conventional sources of energy overshadows the support given to renewable energy sources.

In this paper, we discuss the three main support mechanisms used to finance renewable energy development programs: feed-in-tariffs, tax incentives, and tradable green certificates. Finally, we explain the cross-national incentive policies for clean development mechanisms, which are based on the Kyoto Protocol.

\section{Feed-in-Tariff}

A feed-in-tariff (FIT) is a policy used as a support mechanism to accelerate investment in renewable energy (RE) technologies. According to Couture et al. (2010), a feed-in tariff (FIT) is an energy supply policy focused on supporting the development of new renewable energy projects. FIT is offering long-term purchase agreement for the sale of RE electricity. Couture and Gagnon (2010) pointed to three essential provisions for the success of FIT policies: guaranteed access to the grid, stable and long-term power purchase agreements, and prices should be calculated based on the unit costs of power generated by renewable energy sources. Technologies such as wind power are priced lower than solar photovoltaic (PV) because of the latter's higher cost. However, FIT policies could be considered a controlling regulation measure because of the ability of governments to direct the market according to the rates defined in the contracts. An expectation of lower rates in the future could cause a rush in the market to receive the existing FIT rate. The tariffs may be used as a fixed rate (higher than market price) or as a mark-up that is added to the current market price.

According to the Renewables Global Status Report (GSR 2012), at least 109 countries had used some type of FIT policy by early 2012. FIT policies had been used fully functioning in at least 65 countries and 27 states by 2012 (Martinot and Sawin, 2012). In late 2011, Germany was successful in connecting its one-millionth PV system, mainly driven by the low rate of FIT and the expectation that prices would continue to decrease. Based on the GSR 2012, this newly connected PV system (around 7.5 GW) increased the cumulative installed capacity to $24.8 \mathrm{GW}$, accounting for 3.1 percent of Germany's power generation and almost 8 percent of peak load demand. More evidence for using FIT contract rates as the stimulus for PV system installation are as follows: Italy brought $9.3 \mathrm{GW}$ of PV to benefit from more advantageous rates in 2010; UK increased its capacity to $1 \mathrm{GW}$, driven by two rounds of rate reductions; France operated more than 1.6 GW by changing its FIT rates; China's market has quadrupled mostly due to their national FIT policy, increasing its cumulative installed capacity to $3.1 \mathrm{GW}$ and becoming the dominant player in Asia (Martinot and Sawin, 2012). Figure 1 shows the effects of FIT policy on developing renewable energy installation in the UK. As the figure shows, PV installation has been widely affected by an active FIT policy. 


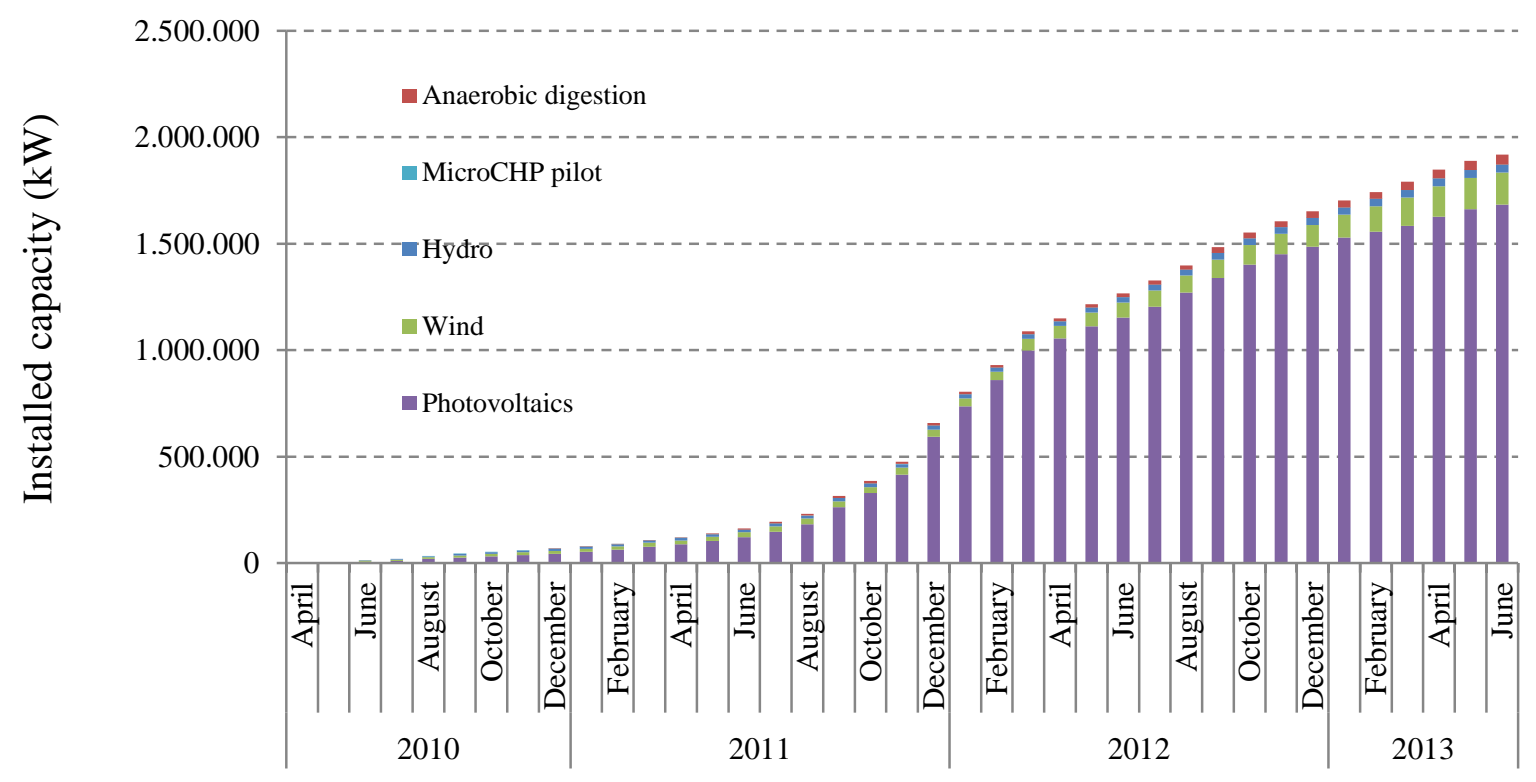

Source: Department of Energy and Climate Change, 2013, UK

Figure 1: Cumulative installed capacity of renewable energy based on FITs in the UK

The UK government introduced an FIT supporting mechanism in April 2010 in order to enhance small-scale renewable energy deployment and low-carbon power generation technologies. This policy covers five technologies: solar PV, wind, hydro, anaerobic digestion, and micro CHP plants. As Figure 1 shows, almost 2 million $\mathrm{kW}$ have been installed based on the FIT supporting mechanism, and the majority of the installed capacity is from solar PV sources. Figure 2 shows the number of cumulative installations in the same period.

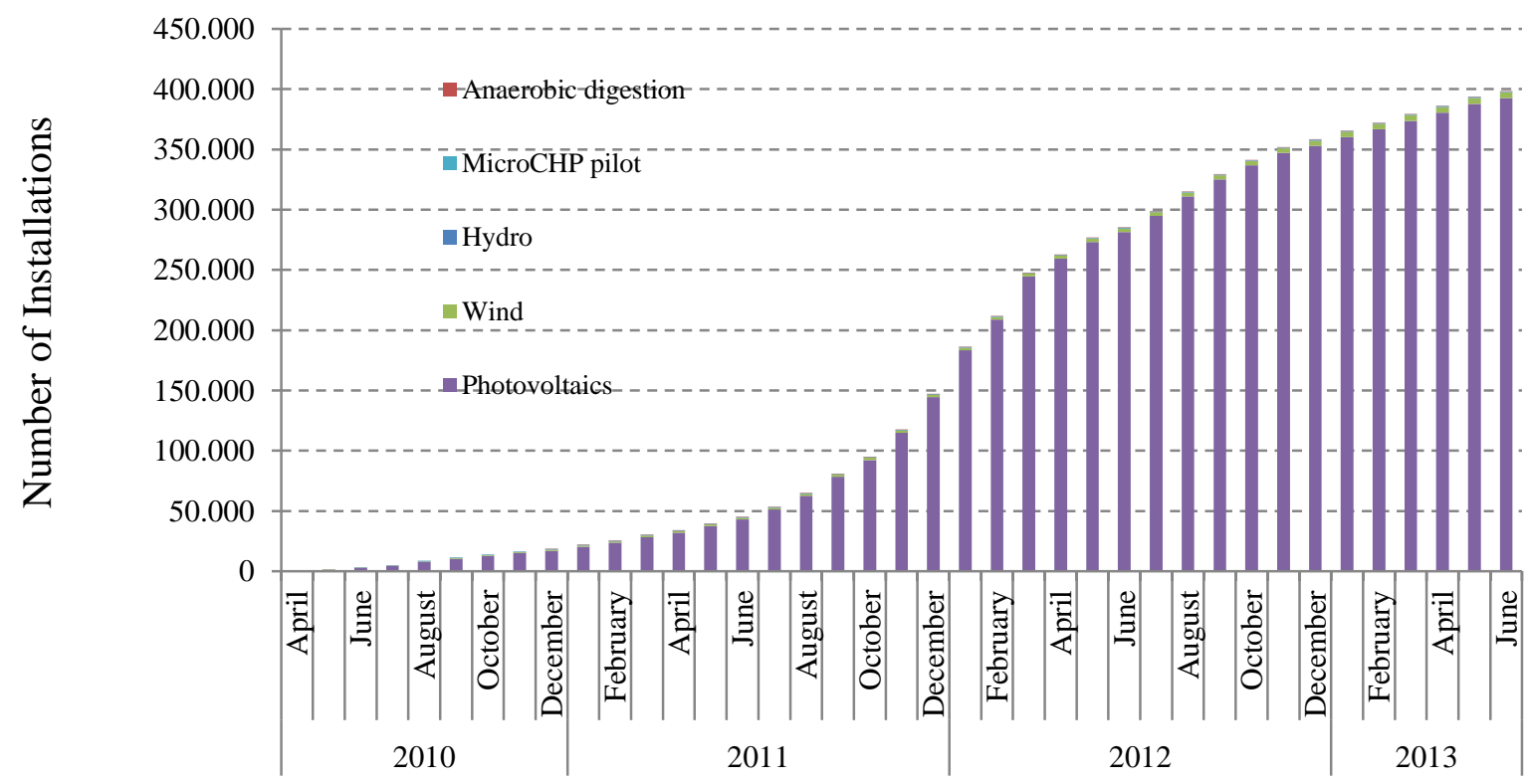

Source: Department of Energy and Climate Change, UK, 2013

Figure 2: Cumulative renewable energy installations based on FITs in the UK 
Financial support mechanisms are gaining importance in the enhancement of renewable energy development. Conventional sources of energy could be replaced with renewable energy technologies (RET) in order to mitigate environmental damage caused by old electricity power generation technology. Ringel (2006) examined the most common types of support systems in the European Union (EU), including FITs and green certificates, in order to evaluate their advantages and disadvantages in terms of effectiveness and efficiency. Based on this analysis, both mechanisms contributed to enhancing the share of power generation by renewable energy. However, many member states tried to shift from a feed-in system to green certificates while experiencing both systems. The results show that FITs are successful in encouraging individuals to use renewable energy sources, with wind energy in Denmark and Germany being the primary source. However, FITs does not have enough capability to create a liberalized, single electricity market. With regard to the EU market, there is an intention to promote the use of green certificates instead of FITs because of the up-coming market for emission certificates. It has been argued that the installation of a harmonized FIT system is almost impossible, for reasons of feasibility and politics at the European level. It has been concluded that no single policy is capable of solving the issue of renewable energy development in a harmonized European market for electricity, leading to the continual debate regarding the application of appropriate support policies.

Rickerson et al. (2007) analyzed support mechanisms in Europe and evaluated their application to policies in the US. They pointed to the debate in Europe about FITs and Renewable Portfolio Standard (RPS), with the aim of applying a single harmonized policy in the US market. They emphasized that the US states are not under federal pressure to comply with a harmonized energy policy. Therefore, they can apply different approaches to take advantage of the renewable energy policy. Considering the experience in Europe and the emerging FIT system as a viable policy in the US, it is expected that this policy will continue to set specific targets for renewable technologies. Some studies have held that FITs could be used for emerging technologies, such as PV, and RPS should be used to enhance near-market renewable energy technologies. Butler and Neuhoff (2008) compared FITs with quota and auction mechanisms to support wind energy development in the UK and Germany by surveying project developers. The result showed that, a frequent criticism of the feed-in tariff is that it does not generate sufficient competition in the market. They concluded that deployment levels are much higher in Germany compared to the UK in terms of installed capacity, which is attributed to the limitation of procedure and cost factors in the UK.

Lesser and Su (2008) examined an economically efficient FIT structure to enhance renewable energy deployment, proposing a two-part FIT system that used both capacity- and marketbased payments to achieve targets. Based on the finding of this research, the following actions should be performed in a two-part FIT: (i) define technologies that are eligible to receive subsidies, (ii) set a desired capacity goal for each technology, (iii) establish a contract period for each FIT, and (iv) set a payment period for the winning auction prices. They argued that the proposed two-part FIT system could eliminate cost errors caused by difficulties faced from using the system based on the Public Utility Regulatory Policies Act of 1978 (PURPA). This Act required utilities to buy electricity from independent renewable energy and co-generation plants, and it proved to be a controversial policy. Under PURPA, the purchase price was based on avoided cost and was left to individual states (Rickerson and Grace, 2007). This Act caused difficulties because it imposed an expensive burden on the utility rate paid by consumers. Lesser and Su (2008) indicated that a two-part FIT policy would create competition and lead to long-term financial stability, thus avoiding overestimates or underestimates in payments to RET developers.

Solana-Peralta et al. (2009) proposed an FIT scheme to take advantage of renewable energy, 
using conventional sources as a hybrid system in isolated areas. They introduced a model that integrated a PV generator into a diesel system for off-grid regions in Ecuador. They compared the results of this integrated system to the existing diesel system under the proposed Renewable Energy Premium Tariff (RPT) plan, an alternative mechanism to deploy renewable energy in off-grid regions. The results showed that the PV-diesel hybrid system is more cost effective than the stand-alone diesel system. They also found that if the optimistic lower value in terms of life cycle cost is considered for PV-diesel hybrid generators, the RPT value for a model with neutral net present value (NPV=0) is estimated at $0.59 \$ / \mathrm{kWh}$ and $0.57 \$ / \mathrm{kWh}$ for 62 and 79 percent PV fraction scenarios, compared to the FIT value of 0.52 $\$ / \mathrm{kWh}$ paid for PVs installed in the mainland. This scheme could be applied to other renewable energy technologies, as well as assist in the introduction of RETs as a sustainable energy option for residents located in isolated, off-grid areas.

Couture and Gagnon (2010) analyzed a variety of feed-in tariff payment models for power generated by renewable energy sources. This was done in order to determine the advantages and disadvantages of different FIT models, based on the dependency on the market price of electricity. They argued that the overall rate of renewable energy enhancement is influenced by the FIT payment structure and its impact on investor risk. They found that marketindependent policies are stronger and more cost-effective than market-dependent options, because of their greater investment security and lower cost of renewable energy deployment. This condition could lead to lower risk and enable investors to have a predictable cash flow. It is also attractive to small investors and community-based projects, because of purchase obligations and lower barriers to entry. Therefore, the advantages associated with marketindependent policies the ability to increase public support, which may lead to the greater participation of individuals, and higher levels of renewable energy penetration into the electricity market. Rigter and Vidican (2010) developed an equation to estimate the cost of PV in order to calculate the optimal FIT that must be applied in China to achieve its ambitious target to expand its share of electricity generated by solar power. For a program starting in 2010 and lasting for 25 years, and assuming a five percent discount rate and an increasing rate of electricity use of two percent per year, the authors estimated that the government be charged \$3.13US for the installation of 1 watt of small scale solar energy. This figure will decrease to $\$ 2.45 U S$ if the program is postponed until the end of 2011. These calculations show why the Chinese government was hesitant about the starting date of the program. They argued that the FIT policy is able to compensate for the negative effects of low electricity prices on the feasibility of solar PV. Moreover, these costs could decrease rapidly over the time because of innovation and technology developments.

Wand and Leuthold (2011) employed a partial equilibrium approach to analyze the potential effects of an FIT policy in Germany for small roof-top solar PV systems installed between 2009 and 2030. They applied a dynamic optimization model that considered learning-bydoing, technology diffusion, and yield dependent demand in order to maximize social welfare. Wand and Leuthold calculated a wide range of effects on social welfare, including the net social cost of 2.014 billion Euros under the Business As Usual (BAU) scenario and net benefits of 7.586 billion Euros from the benefits of solar PV deployment. They argued that the BAU scenario underestimated actual prices, while the positive scenario reflected FIT policies established recently in Germany for the residential PV market. We should also take into account that the negative welfare effect is viewed differently by policymakers in Germany, because of its dependency on fossil fuels and concerns for a secure energy supply in the future. Krajacic et al. (2011) examined the FIT system used in implementing energy storage technologies to overcome the intermittency of renewable energy sources and technical capability of power networks. They analyzed FIT applications for pumped hydro 
storage (PHS), hybrid wind-pumped hydro storage (WHPS), a hydrogen storage system (HSS), PV and batteries, and desalination systems. They also evaluated the FIT mechanism to apply these technologies in some islands and outer areas. After the successful application in these areas, they argued that energy storage tariffs could be applied in main power systems to enhance energy storage usage and to optimize existing utilities in the market.

In a more recent study, Schallenberg and Haas (2012) evaluated two alternative options of FIT, fixed and premium, and examined the evolution of the implementation of both mechanisms in Spain. These mechanisms, which are employed in Spain, have led to successful renewable energy deployment for power generation. The results showed that the direct burden on customers generated by a fixed-FIT policy is smaller than that imposed by the premium, as well as providing higher security for investors. On the other hand, the premium mechanism is market oriented and provides slightly higher income, which could be a more attractive aspect for investors. They stated that the premium mechanism might lead to overcompensation when prices are increased quickly, but this problem could be avoided by setting a cap value. The findings indicated that a fixed-FIT policy should be used for technologies that have not achieved high market penetration and in cases that require building a market environment.

In Portugal, FITs have been the main policy used to enhance power generated by renewable energy sources. Proenca and Aubyn (2013) simulated a model to evaluate economic and environmental impacts of an FIT policy in Portugal. They employed a hybrid topdown/bottom-up general equilibrium model to analyze the interaction among energy, economics, and environmental issues in relation to energy policies. The results showed that the FIT policy provided an effective and cost-efficient instrument to promote renewable energy sources for electricity generation. In addition, the economic adjustment cost was low, and the deployment of renewable energy led to significant reductions in carbon emissions. Jenner et al. (2013) estimated a panel-data model over the years 1992-2008 to analyze the effectiveness of FIT policies for developing solar PV and onshore wind turbines in the EU-26. They applied a fixed-effect model at the country-level and introduced a measure of the return on investment (ROI) to evaluate the strength of the policy. The results showed that solar PV development in Europe was driven by FIT policies through their impact on ROI for investors. The results also implied that the combination of FIT policy, electricity price, and unit cost served as a more accurate determinant for power generation by renewable energy sources than a stand-alone policy measure did.

Insert Table 1: Some empirical studies regarding FIT policies

\section{Tax Incentives}

Tax exemption is used as a fiscal incentive measure to enhance renewable energy deployment in many countries. Tax credits could be applied for the investment, production, or consumption segments of electricity generated by renewable energy sources. Policies aimed at encouraging renewable energy consumption could apply tax credits on the purchase and installation of renewable equipment to facilitate the penetration of renewable energy deployment into the market. For example, a draft bill was introduced in Poland for a renewable heat obligation in private and public buildings, as well as to provide a tax credit to private customers for solar thermal energy (Martinot and Sawin, 2012). Tax policy is also used as a useful instrument to reduce fossil fuel consumption. A carbon tax imposed by a government imposes a higher cost burden for burning fossil fuels and provides an incentive to increase investment in renewable energy sources. Demand for energy could be influenced by 
a carbon tax through the relative cost of using different fuels. Following the Fukushima Daiichi accident, Japan set a target to triple power generation from renewable energy by 2030 over the generated level in 2010. In this regard, Japan released a new FIT system to support renewable energy and to employ other subsidy mechanisms, such as tax credits, investment grants, and loans (IEA, 2012b).

Tax credits used as a supportive policy in some countries, such as Germany, could be applied in other countries, especially since the lack of competitiveness in conventional sources of energy is a typical barrier for most countries (Gutermuth, 1998). The exemption of fuels produced by renewable energy sources, such as biomasses, from other taxes was applied by Germany, increasing the competitiveness of renewable sources with the highly taxed conventional diesel fuel. Consequently, sales rose from 40,000t in 1996 to 100,000t in 1997. A similar policy was applied to electrical vehicles, exempting EVs from the motor vehicle tax for five years. An attractive feature of this instrument is that it makes cash available. Therefore, it could be an important financial incentive for private investors and an opportunity to make small investments because it directly increases investor liquidity. Many economists believe that employing a carbon emission tax or emission trading mechanism is considered a good policy to mitigate emissions at the lowest cost (Kalkuhl et al., 2013).

Kahn and Goldman (1987) analyzed the sensitivity of the renewable energy and cogeneration project's internal rate of return (IRR) based on tax changes created by the US federal tax code under PURPA. The electricity market was stimulated by tax incentives under PUPRA. Kahn and Goldman investigated six different technologies to evaluate the effects of tax reform on the financial viability of projects. Based on their calculations, capital intensive projects, such as wind turbines, small hydro, geothermal and wood-fired electricity, were not financially viable because of the expiration of energy tax credits. The results showed that gas-fired cogeneration technology is the most beneficial under the tax reform. Walsh (1989) applied a two-period utility maximization model of household behavior to investigate the relationship between federal and state tax credits and energy saving improvement in the US. The federal government reduced the income tax liability by 15 percent of expenditure for conservation facilities from 1977 to 1986 . The results indicated that tax credits were not an effective solution to subsidizing energy conservation activities. This could be the result of the small discount rate applied by the tax reform, the inconvenience of claiming the credit, or the lack of knowledge about the effects of price reduction.

Alfsen et al. (1995) simulated a model to assess the possible effects of a carbon tax in Western Europe and the partial deregulation of the power generation industry on $\mathrm{CO}_{2}, \mathrm{SO}_{2}$ and $\mathrm{NO}_{\mathrm{x}}$ emissions. They studied two regimes, plan-efficient and cost-efficient, in order to examine the effectiveness of carbon tax. They found that emissions were reduced by the European Community (EC) tax by 6 to 10 percent under both regimes compared to a scenario without the tax. The regime change from the plan-efficient to the cost-efficient caused a reduction of 3 percent in $\mathrm{CO}_{2}$ and $\mathrm{NO}_{\mathrm{x}}$ emissions, while $\mathrm{SO}_{2}$ was reduced by 13 percent. The results showed that an economic instrument for carbon emission reduction is able to influence the emissions of $\mathrm{SO}_{2}$ and $\mathrm{NO}_{\mathrm{x}}$. Hassett and Metcalf (1995) estimated a panel data model of individual tax returns and variations in state tax policy in order to evaluate the impact of tax policies on investment in residential energy conservation in the US. They concluded that a point change of 10 percent in the rate of tax incentives for energy investment could increase the probability of investment by 24 percent. Kahn (1996) examined the impact of tax credits set by the US government based on the Energy Policy Act (EPAct) of 1992 to enhance renewable energy technologies. The results showed that a production tax credit was ineffective in providing an incentive to invest in wind turbine power plants because it raised the financing cost. Therefore, the tax credit might not be able to reduce the unit cost of 
electricity generated by wind turbines compared to the plan with no incentive. Consequently, the effect of the production tax credit could be minimal.

Brännlund and Nordström (2004) formulated an econometric model of non-durable consumer demand in Sweden to analyze consumer response and welfare effects of changing energy or environmental policy. The results showed that households living in populated areas were more influenced by a $\mathrm{CO}_{2}$ tax, indicating that carbon tax has a regional distribution effect. In terms of environmental effects, petrol demand decreased by almost 11 percent, which affects carbon emissions. The findings showed that the distribution of the tax burden and welfare loss was uneven, because the tax revenue was not returned at an even rate. Barradale (2010) examined the impact of repeated expiration and a short-term renewal federal production tax credit (PTC) on wind power investment. The federal tax revision created an on-off pattern, which led to a boom-bust cycle in wind power plant investment in the US. This led to a severe downward trend in investment, because of the high cost of ramp-up and ramp-down. The results implied that wind power is not feasible in the absence of PTC. However, Barradale found that it was formed due to the negotiation dynamics in the power purchase agreement in the face of PTC uncertainty. Therefore, an incentive instrument applied to enhancing renewable energy production may be changed to a disincentive form if it causes uncertainty.

Galinato and Yodar (2010) introduced an integrated tax-subsidy policy for carbon emission reduction, which is considered a compromise between the standard Pigovian tax and a traditional indirect subsidy. They argued that environmental taxes on energy are not popular politically, because the taxes imposed on fossil fuels could lead to higher energy prices. Moreover, subsidies paid for renewable energy fuels are funded mainly by labor or income taxes. Galinato and Yodar suggested that revenues from carbon taxes could be used to fund subsidies for the production of low-emitter fuels. Therefore, the carbon tax and subsidy mechanism are revenue neutral within the energy industry. Levin et al. (2011) developed an energy optimization model and applied it to the investigation of the effects of the Renewable Energy Standard and carbon tax in the state of Georgia in the US. The results showed that power generated from biomass co-generation at coal plants could be considered a low-cost option, but the potential was limited. The findings indicated that a constant carbon tax through the year 2030 would lead to the replacement of coal with natural gas, instead of generating electricity from renewable energy sources. Based on their calculation, the low-cost biomass had the lowest levelized costs of electricity in all scenarios. The importance of a properly designed policy in order to achieve targets was emphasized in this research.

Pablo-Romero et al. (2013) investigated a variety of instruments, such as tax incentives applied in Spain, to enhance solar thermal energy deployment. They argued that tax incentives have not had a sufficient impact on solar thermal energy deployment, because of regulatory changes at the national level, which led to complications in the system. It has also been stated that tax incentives would be more effective if they were associated with a proper financing mechanism. In this regard, Lehmann (2013) employed an analytical partialequilibrium model of the electricity sector to show that an optimal policy to mitigate climate change could be designed efficiently by applying an emission tax along with a subsidy for renewable energy sources. Lehmann analyzed the performance of a revenue-neutral fixed tariff and relevant differences compared to a government-funded premium tariff. He argued that a premium tariff policy may be seen as a better option than non-continuous adoption, but some important parameters (e.g., increasing investment uncertainty and transaction costs, concerns associated with funding tariffs from public budgets, and breaking EU completion law) should be taken into account. It has been suggested that the optimal tax rate should be less than the Pigovian level, differentiated across the fossil fuels, and modified continuously, 
based on technological change. This paper implies that in the presence of learning-by-doing for renewable energy technologies, a combination of an emission tax and a subsidy that is modified continuously could be considered an optimal strategy.

Insert Table 2: Some empirical studies regarding tax incentive policies

\section{Renewable Portfolio Standard}

As previously mentioned, governments use a variety of policies to promote renewable energy. The renewable portfolio standard (RPS) is one of the most common policies used with FITs. In contrast to the FIT policy, which is price-based (fixed-price and premium-price), the RPS policy is quantity-based. This instrument requires companies to increase the amount of power generated by renewable energy sources. The RPS mechanism obligates utility companies to generate a specified share of their electricity by renewable energy. By doing so, they receive tradable certificates for every unit (for example, $1 \mathrm{MWh}$ ) of power generated; these are called tradable green certificates. Unlike the FIT mechanism, in which the government guarantees the purchase of generated electricity, the RPS mechanism relies on the private market for its implementation. Therefore, there is greater price competition across different types of renewable energy technologies. By early 2010, RPS was in place in 56 states, provinces, and countries, including more than half of US states (Martinot and Sawin, 2012). RPS policy is usually associated with the certificate trading mechanism. In the US, a credit multiplier is applied to promote specific types of renewable energy technology. For instance, a wind multiplier means that one MWh of power generated by wind technology could equal three certificates for the generator (M.J. Beck Consulting, 2009). Therefore, governments could use the credit multiplier as an instrument to direct revenue, investment, and job creation to a particular type of technology.

The EU has experience with both FIT and RPS mechanisms. However, the former has led to the rapid expansion of the capacity for renewable energy, and thus has been employed more than the latter. Experience with FIT is limited in the US, which has focused more on RPS (Rickerson and Grace, 2007). Although RPS policies have diffused rapidly across the US, FIT policy is gaining in attractiveness to policy makers because of its success in the EU, particularly Germany. As of June 2010, the RPS mechanism had been applied by 29 states in the US, with another seven having established nonbinding renewable energy goals. Almost 65 percent of the total wind capacity additions from 2001 to 2007 in the US were motivated by state RPS policies (Wiser, 2008). Some states have experienced rapid renewable energy expansion by these policies, as Texas has achieved its 2015 RPS target of 5 GW installed capacity six years earlier than scheduled (Edenhofer et al., 2011). According to the GSR 2012 report, by 2010, quotas or RPS were used in 69 states, provinces, and countries. Two additional countries implemented this policy in 2011 bringing the total to 71, slightly less than the 92 countries utilizing FIT policies (Martinot and Sawin, 2012). In South Korea, an FIT policy that was operational through 2011 was changed to a RPS policy in 2012. Considering that RPS policies are usually associated with trading certificates, in 2011 India launched a new Renewable Energy Certificate mechanism linked to the current quota system.

Espey (2001) discussed one of the main support mechanisms that was introduced to promote renewable energy deployment and examined the possible effects of applying RPS based on theoretical concepts and practical evidence. Espey argued that the RPS could not be considered a stand-alone solution that would enhance renewable energy sources. However, the advantages of the RPS make it an ideal starting point in the transition to an international trading system if a well-designed mechanism is employed. Berry and Jaccard (2001) 
analyzed the implementation of RPS in three European countries (Netherland, Denmark, and Italy), nine US states, and Australia. They concluded that the RPS is generally applied to generators instead of end users. Although the RPS system is managed by the government in Europe, it is administered by a delegation of government and independent utility regulators in the US and Australia. Lauber (2004) compared FIT and RPS mechanisms as two options for a harmonized community framework. Lauber argued that these systems could not be measured by a common standard because they have different purposes. The FIT mechanism is appropriate to support renewable technology development and the equipment industry, whereas the RPS system is more suitable in the phase of near-market competitiveness than in the early stage of technology development.

Wiser et al. (2005, p 261) examined experiences with RPS design, application, and effects in 13 US states. The results showed that RPS performed successfully in Texas, Iowa, and Minnesota. However, it was not effective because the policies were poorly designed. Some critical design pitfalls were experienced by states, including the following: "narrow applicability, poorly balanced supply-demand conditions, insufficient duration and stability of targets, insufficient enforcement, and poorly defined or non-existent contracting standards and cost recovery mechanisms for regulated utilities and providers of last resort."

Nishio and Asano (2006) applied a quantitative analysis to evaluate the supply amount and marginal prices of electricity generated by renewable energy sources under the RPS mechanism in Japan. The results showed that the majority of power supplied under RPS was generated by wind and biomass energy. In addition, the purchase of certificates from generators in other regions and trading among retailers enabled the RPS system to be implemented effectively. Based on the analysis of the dynamic supply curve, the marginal price would increase according to the amount of electricity supplied. Kydes (2007) analyzed the effects of applying a federal 20 percent non-hydropower RPS on US energy markets by 2020. The estimates suggested that this policy would be effective in enhancing renewable energy technologies and reducing emissions of $\mathrm{NO}_{\mathrm{x}}$ by 6 percent, mercury by 4 percent and $\mathrm{CO}_{2}$ by 16.5 percent. It was estimated that the total electricity cost for customers would increase by almost 3 percent, making a significant cost increase of 35 to 60 billion dollars for the power generation industry by 2020 .

Carley (2009) examined the causal effects of RPS policies in states in the US on the percentage of renewable energy deployment. They applied a standard fixed effects model to evaluate the effectiveness of state energy programs from 1998 to 2006. The results showed significant potential for RPS policies and that an increase in the number of states that implemented this policy could lead to an increase in RE deployment. The results indicated that the percentages of RE generation were lower in deregulated states than in regulated states, implying that competitive markets stimulate RE investment. Yin and Powers (2010) applied a panel data model to determine the impact of state-level RPS policies in the US and introduced an index to measure RPS stringency. Their findings showed that RPS policies significantly affected in-state RE development. The results also showed that allowing out-ofstate certificate trading had a negative impact on the effectiveness of RPS deployment. Moon et al. (2011) performed an economic analysis of biomass power generated by two technologies under an RPS scheme in order to compare the impact of the biomass on combined heat and power (CHP) system capacity. The Korean government introduced an FIT program in 2006 but changed it to RPS because it failed to achieve the preset targets in recent years. The results showed that under the current infrastructure and technology levels, biomass gasification in CHP in the range of 0.5 to $5 \mathrm{MW}_{\mathrm{e}}$ could be considered a potential starting point for initiating an RPS mechanism. 
Buckman (2011) investigated the effectiveness of banding and carve-outs as two modifications of the RPS mechanism used to support high-cost types of renewable energy technologies. The UK and Italy used these modifications as particular examples of analysis banding. The US is chosen as the example for a carve-out device. The results showed that both methods have strengths and weakness for the enabling of markets to enhance renewable energy deployment. They concluded that banding might be better than carve-outs to support the high-cost renewable energy technologies. Dong (2012) examined the effectiveness of FIT and RPS to enhance wind power generation by applying a panel data analysis of 53 countries over the years 2005 to 2009. The results indicated that FIT policies increased power capacity by 1800 MW over RPS mechanisms. This capacity would increase to $2000 \mathrm{MW}$ when the timing of the policy was taken into account, because the FIT system was started earlier than the RPS mechanism. There was no significant difference between FIT and RPS in terms of annual capacity. Fagiani et al. (2013) simulated a model for the period 2012 to 2050 in order to analyze the effects of investors' risk aversion driven by profit maximization on FIT and the certificate market system. The results showed that although FIT policy could achieve better economic efficiency than RPS could, it depended strongly on regulators' decisions. In contrast, RPSs showed better performance compared to FITs in terms of cost-efficiency when the degree of risk aversion was moderate.

The comparison of FIT and RPS policies showed that the FIT policy was good when a policy to develop renewable energy sources with a low level of risk for investors is required. However, the RPS is appropriate when a market view policy is applied by the government. Europe intends to organize a single harmonized FIT system, due to the differences in policies applied across the member countries, even though evidence suggests that this may be impossible in practice. The RPS system has not been developed in Europe, because most European countries use the FIT system. Hence, it seems that FIT polices are suitable for the encouragement to develop renewable energy sources. However, an RPS system should be applied after the implementation of renewable energy sources reaches a certain level.

Insert Table 3: Some empirical results regarding RPS policies

\section{Cross-National Incentive Policies}

Cross-national incentive policies can be studied from different points of view, including the transfer of climate change mitigation technologies, emission trading schemes, and the clean development mechanism (CDM) derived from the Kyoto Protocol. Given the considerable scale of effort required to reduce greenhouse gas emissions, it is almost impossible for all countries to produce environmentally friendly technologies by themselves. The OECD and the World Bank have shown that climate-mitigation technology trading could be affected by non-tariff measures, which would also help them to promote technologies (Tébar Less and McMillan, 2005). Trade barriers are not the only barriers to commodity movement. Total technology is constituted by the knowledge, skills, and services associated with installation and operation. Steenblik and Kim (2009) investigated the effects of tariff and non-tariff barriers on trading a selection of carbon-change-mitigation technologies (CCMTs) identified by the Intergovernmental Panel on Climate Change (IPCC) and the IEA. These included combined heat and power, district heating and cooling, solar heating and cooling, and energy efficiency motor systems. They concluded that is necessary for technology importers to review their policies in order to facilitate the diffusion of CCMT technologies made and developed in OECD countries. Adequate environmental regulations, removal or reduction of trade barriers, adequate intellectual property rights regimes, and appropriate financing mechanisms were considered incentives to transfer renewable energy technologies across 
countries (Tébar Less and McMillan, 2005).

The Kyoto Protocol introduced three mechanisms to mitigate GHG emissions: (i) emission trading, (ii) CDM, and (iii) joint implementation (JI). Emission trading is based on an allowance transition that enables a country (listed in Annex B) to trade emission permits. In contrast, CDM and JI are classified as project-based. The European Union Emission Trading Scheme (EU ETS) is an essential part of the EU climate change policy. The allowance mechanism in ETS is based on three methods: grandfathering, benchmarking and auctioning (Koh, 2010). In this system, which was applied from 2005 to 2012, nearly all permits were grandfathered (Bernard and Vielle, 2009). Based on the mechanism applied to mitigate emissions, incentives could be different. In the case of emission trading, the renewable energy certificate mechanism derived from the RPS has gained importance. As previously noted, the EU aims to harmonize support mechanisms in order to facilitate market creation for trading certificates across member nations. A CDM or JI mechanism approach is similar to an investment project, because it is able to earn both financial returns and carbon credits. Carbon credits have monetary value which affect net financial returns.

Carbon credit transactions enable the host countries to receive significant amounts of foreign investment. CDM is specifically designed as a mechanism to channel foreign investment into non-Annex I countries (Koh, 2010). Therefore, the incentives for using CDM facilities across countries are similar to the incentives used to attract foreign direct investment. For example, it is important to consider any regulation that may create a limitation to the inflow of FDI, including the restrictions on the profit repatriation of investors. Some countries may offer investment incentives and tax concessions to promote CDM projects. Krey (2004) examined 15 unilateral potential CDM projects in India and found that average transaction costs were estimated at a $0.06-0.47 \$ / \mathrm{tCO}_{2}$ equivalent, which corresponds to approximately 76 to 88 percent of the total transaction costs of the projects. Chaurey and Kandpal (2009) analyzed the carbon abatement potential of solar home systems (SHS) in India and estimated that a bundled project of 20,000 SHS could return almost Rs 1.9 million annually at $10 \$ / \mathrm{tCO}_{2}$ after expenses of 20 percent for pre-implementation transaction costs. Of course, the balance between demand and supply should be taken into account. The total demand in the Kyoto Protocol from 2008 to 2012 was estimated at $1222 \mathrm{MtCO}_{2}$, whereas the supply was over 3000 $\mathrm{MtCO}_{2}$. Additionally, the Green Investment Scheme developed by Russia and East European countries would bring a return of more than $1800 \mathrm{MtCO}_{2}$ (Bhattacharyya, 2011). On the other hand, these numbers demonstrate the potential capacity of carbon emission reduction in several countries. By other means, there would be a large capacity available to reduce emissions if a well-designed support mechanism were in place.

\section{Summary and Conclusion}

Alternative policies for environmental protection are applied in the form of economics (incentive) or regulations (non-incentive). Economic policies could be an incentive for using renewable energy or charging taxes imposed on emission generation or fossil-fuel consumption. Three types of support mechanisms are widely employed: (i) feed-in-tariff, (ii) tax incentives, and (iii) tradable green certificates. Tax credits could be applied to the investment, production, or consumption segments of electricity generated by renewable energy sources. The main reason that this instrument is attractive is that it makes cash available. Therefore, it could be an important financial incentive for private investors, as well as an opportunity to make small investments, because it directly increases investor liquidity. Couture and Gagnon (2010) pointed to three essential provisions for the success of FIT policies: guaranteed access to the grid, stable and long-term power purchase agreements, and 
prices should be calculated based on the unit costs of power generated by renewable energy sources.

In contrast to the FIT policy, which is price-based (fixed-price and premium-price), the RPS policy is quantity-based. This instrument requires companies to increase the amount of power generated by renewable energy sources. The comparison of FIT and RPS policies showed that the FIT policy is preferred when a policy to develop renewable energy sources with a low level of risk for investors is required. However, the RPS policy is appropriate when a market view policy is applied by the government. Although Europe has attempted to organize a single harmonized FIT system, it is believed to be impossible due to the vast differences in policies across the member countries. The RPS system has not been developed in Europe, as most European countries have previously instituted the FIT system. In this regard, it seems that FIT polices are suitable to encourage the development of renewable energy sources. However, the RPS system should be applied after the implementation of renewable energy sources has reached a certain level.

\section{References}

Alfsen, K. H., Birkelund, H., \& Aaserud, M. (1995). Impacts of an EC carbon/energy tax and deregulating thermal power supply on $\mathrm{CO} 2, \mathrm{SO} 2$ and NOx emissions. Environmental and Resource Economics, 5(2), 165-189.

Barradale, M. J. (2010). Impact of public policy uncertainty on renewable energy investment: Wind power and the production tax credit. Energy Policy, 38(12), 7698-7709. doi: 10.1016/j.enpol.2010.08.021

Bernard, A., \& Vielle, M. (2009). Assessment of European Union transition scenarios with a special focus on the issue of carbon leakage. Energy Economics, 31, S274-S284.

Berry, T., \& Jaccard, M. (2001). The renewable portfolio standard: design considerations and an implementation survey. Energy Policy, 29(4), 263-277. doi: 10.1016/s03014215(00)00126-9

Bhattacharyya, S. C. (2011). Energy Economics: Concepts, Issues, Markets and Governance. London: Springer.

Brännlund, R., \& Nordström, J. (2004). Carbon tax simulations using a household demand model. European Economic Review, 48(1), 211-233.

Buckman, G. (2011). The effectiveness of Renewable Portfolio Standard banding and carveouts in supporting high-cost types of renewable electricity. Energy Policy, 39(7), 4105-4114. doi: 10.1016/j.enpol.2011.03.075

Butler, L., \& Neuhoff, K. (2008). Comparison of feed-in tariff, quota and auction mechanisms to support wind power development. Renewable Energy, 33(8), 18541867. doi: 10.1016/j.renene.2007.10.008

Carley, S. (2009). State renewable energy electricity policies: An empirical evaluation of effectiveness. Energy Policy, 37(8), 3071-3081.

Chaurey, A., \& Kandpal, T. (2009). Carbon abatement potential of solar home systems in India and their cost reduction due to carbon finance. Energy Policy, 37(1), 115-125.

Couture, T., \& Gagnon, Y. (2010). An analysis of feed-in tariff remuneration models: Implications for renewable energy investment. Energy Policy, 38(2), 955-965. doi: 10.1016/j.enpol.2009.10.047

Couture, T. D., Cory, K., Kreycik, C., \& Williams, E. (2010). Policymaker's Guide to Feed-in Tariff Policy Design: National Renewable Energy Laboratory (NREL), Golden, CO.

Dong, C. G. (2012). Feed-in tariff vs. renewable portfolio standard: An empirical test of their relative effectiveness in promoting wind capacity development. Energy Policy, 42, 
476-485. doi: 10.1016/j.enpol.2011.12.014

Edenhofer, O., Pichs-Madruga, R., Sokona, Y., Seyboth, K., Kadner, S., Zwickel, T., . . von Stechow, C. (2011). Renewable Energy Sources and Climate Change Mitigation: Special Report of the Intergovernmental Panel on Climate Change: Intergovernmental Panel on Climate Change.

Edwards P.E.T., A.E. Sutton-Grier and G.E. Coyle (2013). Investing in nature: Restoring coastal habitat blue infrastructure and green job creation. Marine Policy 38, 65-71.

Espey, S. (2001). Renewables portfolio standard: a means for trade with electricity from renewable energy sources? Energy Policy, 29(7), 557-566. doi: 10.1016/s03014215(00)00157-9

Fagiani, R., Barquin, J., \& Hakvoort, R. (2013). Risk-based assessment of the cost-efficiency and the effectivity of renewable energy support schemes: Certificate markets versus feed-in tariffs. Energy Policy, 55, 648-661. doi: 10.1016/j.enpol.2012.12.066

Gai C., C. Wang, J. Chen and S. Wang (2011). The relationship between green economy and green jobs: myth or reality? The case of China's power generation sector. Energy 36(10), 5994-6003.

Galinato, G. I., \& Yoder, J. K. (2010). An integrated tax-subsidy policy for carbon emission reduction. Resource and Energy Economics, 32(3), 310-326.

Gutermuth, P. G. (1998). Financial measures by the state for the enhanced deployment of renewable energies. Solar Energy, 64(1-3), 67-78. doi: 10.1016/s0038092x(98)00066-8

Hassett, K. A., \& Metcalf, G. E. (1995). Energy tax credits and residential conservation investment: Evidence from panel data. Journal of Public Economics, 57(2), 201-217.

IEA. (2012a). Energy Technology Perspectives 2012: OECD Publishing.

IEA. (2012b). World Energy Outlook 2012: OECD Publishing.

Jenner, S., Groba, F., \& Indvik, J. (2013). Assessing the strength and effectiveness of renewable electricity feed-in tariffs in European Union countries. Energy Policy, 52, 385-401. doi: 10.1016/j.enpol.2012.09.046

Kahn, E. (1996). The production tax credit for wind turbine powerplants is an ineffective incentive. Energy policy, 24(5), 427-435.

Kahn, E., \& Goldman, C. A. (1987). Impact of tax-reform on renewable energy and cogeneration projects. Energy Economics, 9(4), 215-226. doi: 10.1016/01409883(87)90029-6

Kalkuhl, M., Edenhofer, O., \& Lessmann, K. (2013). Renewable energy subsidies: Secondbest policy or fatal aberration for mitigation? Resource and Energy Economics, 35(3), 217-234.

Koh, K. L. (2010). Crucial issues in climate change and the Kyoto Protocol: Asia and the world: World Scientific Publishing Company.

Krajacic, G., Duic, N., Tsikalakis, A., Zoulias, M., Caralis, G., Panteri, E., \& Carvalho, M. D. (2011). Feed-in tariffs for promotion of energy storage technologies. Energy Policy, 39(3), 1410-1425. doi: 10.1016/j.enpol.2010.12.013

Krey, M. Transaction Costs of CDM Projects in India-An Empirical Survey.

Kydes, A. S. (2007). Impacts of a renewable portfolio generation standard on US energy markets. Energy Policy, 35(2), 809-814. doi: 10.1016/j.enpol.2006.03.002

Lauber, V. (2004). REFIT and RPS: options for a harmonised Community framework. Energy policy, 32(12), 1405-1414.

Lehmann, P. (2013). Supplementing an emissions tax by a feed-in tariff for renewable electricity to address learning spillovers. Energy Policy 61, 635-641.

Lesser, J. A., \& Su, X. J. (2008). Design of an economically efficient feed-in tariff structure for renewable energy development. Energy Policy, 36(3), 981-990. doi: 
10.1016/j.enpol.2007.11.007

Levin, T., Thomas, V. M., \& Lee, A. J. (2011). State-scale evaluation of renewable electricity policy: The role of renewable electricity credits and carbon taxes. Energy Policy, 39(2), 950-960.

M.J. Beck Consulting, L. (2009). Renewable Portfolio Standards (RPS). Retrieved 26 July, 2013

Martinot, E., \& Sawin, J. (2012). Renewables global status report: 2012 update.

Moon, J. H., Lee, J. W., \& Lee, U. D. (2011). Economic analysis of biomass power generation schemes under renewable energy initiative with Renewable Portfolio Standards (RPS) in Korea. Bioresource Technology, 102(20), 9550-9557. doi: 10.1016/j.biortech.2011.07.041

Nishio, K., \& Asano, H. (2006). Supply amount and marginal price of renewable electricity under the renewables portfolio standard in Japan. Energy Policy, 34(15), 2373-2387. doi: 10.1016/j.enpol.2005.04.008

Pablo-Romero, M., Sánchez-Braza, A., \& Pérez, M. (2013). Incentives to promote solar thermal energy in Spain. Renewable and Sustainable Energy Reviews, 22, 198-208.

Pop O., G.C. Dina and C. Martin (2011). Promoting the corporate social responsibility for a green economy and innovative jobs. Procedia Social and Behavioral Sciences 15, 1020 1023.

Proenca, S., \& St Aubyn, M. (2013). Hybrid modeling to support energy-climate policy: Effects of feed-in tariffs to promote renewable energy in Portugal. Energy Economics, 38, 176-185. doi: 10.1016/j.eneco.2013.02.013

Rickerson, W., \& Grace, R. C. (2007). The debate over fixed price incentives for renewable electricity in Europe and the United States: Fallout and future directions. A White Paper Prepared for The Heinrich Böll Foundation.

Rickerson, W. H., Sawin, J. L., \& Grace, R. C. (2007). If the shoe FITs: Using feed-in tariffs to meet US renewable electricity targets. The Electricity Journal, 20(4), 73-86.

Rigter, J., \& Vidican, G. (2010). Cost and optimal feed-in tariff for small scale photovoltaic systems in China. Energy Policy, 38(11), 6989-7000. doi: 10.1016/j.enpol.2010.07.014

Ringel, M. (2006). Fostering the use of renewable energies in the European Union: the race between feed-in tariffs and green certificates. Renewable Energy, 31(1), 1-17. doi: 10.1016/j.renene.2005.03.015

Schallenberg-Rodriguez, J., \& Haas, R. (2012). Fixed feed-in tariff versus premium: A review of the current Spanish system. Renewable \& Sustainable Energy Reviews, 16(1), 293305. doi: 10.1016/j.rser.2011.07.155

Solano-Peralta, M., Moner-Girona, M., van Sark, W., \& Vallve, X. (2009). "Tropicalisation" of Feed-in Tariffs: A custom-made support scheme for hybrid PV/diesel systems in isolated regions. Renewable \& Sustainable Energy Reviews, 13(9), 2279-2294. doi: 10.1016/j.rser.2009.06.022

Steenblik, R., \& Kim, J. A. (2009). Facilitating Trade in Selected Climate Change Mitigation Technologies in the Energy Supply, Buildings, and Industry Sectors.OECD Trade and Environment Working Paper No. 2009-02

Tébar Less, C., \& McMillan, S. (2005). Achieving the Successful Transfer of Environmentally Sound Technologies.OECD Trade and Environment Working Paper No. 2005-2

Walsh, M. J. (1989). Energy tax credits and housing improvement. Energy Economics, 11(4), 275-284.

Wand, R., \& Leuthold, F. (2011). Feed-in tariffs for photovoltaics: Learning by doing in Germany? Applied Energy, 88(12), 4387-4399. doi: 10.1016/j.apenergy.2011.05.015

Wiser, R. (2008). Renewable Portfolio Standards in the United States-A Status Report with 
Data Through 2007.

Wiser, R., Porter, K., \& Grace, R. (2005). Evaluating experience with renewables portfolio standards in the United States. Mitigation and Adaptation Strategies for Global Change, 10(2), 237-263.

Yi H. (2013). Clean energy policies and green jobs: an evaluation of green jobs in U.S. metropolitan areas. Energy Policy 56, 644-652.

Yin, H. T., \& Powers, N. (2010). Do state renewable portfolio standards promote in-state renewable generation? Energy Policy, 38(2), 1140-1149. doi: 10.1016/j.enpol.2009.10.067 
Table 1: Some empirical studies regarding FIT policies

\begin{tabular}{|c|c|c|}
\hline Author & Subject & Result \\
\hline Ringel (2006) & $\begin{array}{l}\text { Fostering the use of } \\
\text { renewable energies in the } \\
\text { EU, comparing FITs and } \\
\text { green certificates }\end{array}$ & $\begin{array}{l}\text { There is an intention to promote green certificates instead of } \\
\text { FITs due to up-coming markets for emission certificates. } \\
\text { Using a harmonized FIT is almost impossible in Europe. }\end{array}$ \\
\hline $\begin{array}{l}\text { Rickerson et al. } \\
\text { (2007) }\end{array}$ & $\begin{array}{l}\text { Using FIT to meet US } \\
\text { renewable targets }\end{array}$ & $\begin{array}{l}\text { The US can apply different approaches to take advantage of } \\
\text { the renewable energy policy. FIT could be used for emerging } \\
\text { technologies and RPS should be used to enhance near- } \\
\text { market energy technologies. }\end{array}$ \\
\hline $\begin{array}{l}\text { Butler \& } \\
\text { Neuhoff (2008) }\end{array}$ & $\begin{array}{l}\text { Comparison of FIT, quota } \\
\text { and auction to support } \\
\text { wind power }\end{array}$ & $\begin{array}{l}\text { They noted very low levels of competition at the operational } \\
\text { stage for all three funding schemes. Deployment levels are } \\
\text { much higher in Germany compared to the UK. }\end{array}$ \\
\hline $\begin{array}{l}\text { Lesser \& Su } \\
(2008)\end{array}$ & $\begin{array}{l}\text { Design of an economical } \\
\text { FIT structure }\end{array}$ & $\begin{array}{l}\text { They proposed a two-part FIT system targeting both capacity } \\
\text { and market-based payment to achieve targets. }\end{array}$ \\
\hline $\begin{array}{l}\text { Solano-Peralta et } \\
\text { al. (2009) }\end{array}$ & $\begin{array}{l}\text { Custom-made support } \\
\text { scheme for hybrid system } \\
\text { in isolated regions }\end{array}$ & $\begin{array}{l}\text { The proposed Renewable Energy Premium Tariff (RPT) plan } \\
\text { for off-grid regions. RPT value for a model with NPV=0 is } \\
\text { estimated at } 0.59 \$ / \mathrm{kWh} \text { and } 0.57 \$ / \mathrm{kWh} \text { for } 62 \text { and } 79 \\
\text { percent PV fraction scenarios, compared to } 0.52 \$ / \mathrm{kWh} \text { FIT } \\
\text { values paid for PV installed in mainland Ecuador. }\end{array}$ \\
\hline $\begin{array}{l}\text { Couture \& } \\
\text { Gognon (2010) }\end{array}$ & $\begin{array}{l}\text { Analysis of FIT } \\
\text { remuneration models }\end{array}$ & $\begin{array}{l}\text { Market-independent policies provide a stronger and more } \\
\text { cost-effective policy compared to market-dependent options } \\
\text { due to greater investment security and a lower cost for } \\
\text { renewable energy deployment. }\end{array}$ \\
\hline $\begin{array}{l}\text { Rigter \& Vidican } \\
\text { (2010) }\end{array}$ & $\begin{array}{l}\text { Cost and optimal FIT for } \\
\text { small scale PV in China }\end{array}$ & $\begin{array}{l}\text { FIT policy is able to compensate negative impacts of low } \\
\text { electricity prices on feasibility of solar PV and these costs } \\
\text { could decrease rapidly over the time as a result of innovation } \\
\text { and technology development. }\end{array}$ \\
\hline $\begin{array}{l}\text { Wand \& } \\
\text { Leuthold (2011) }\end{array}$ & FIT for PV in Germany & $\begin{array}{l}\text { They found a wide range of impacts on social welfare, from } \\
\text { net social cost of } 2.014 \text { billion Euros under a Business As } \\
\text { Usual (BAU) scenario to net benefits of } 7.586 \text { billion Euros } \\
\text { under a positive perspective of solar PV deployment. }\end{array}$ \\
\hline $\begin{array}{l}\text { Krajacic et al. } \\
(2011)\end{array}$ & $\begin{array}{l}\text { FIT for promotion of } \\
\text { energy storage } \\
\text { technologies }\end{array}$ & $\begin{array}{l}\text { Energy storage tariffs could be applied in main power } \\
\text { systems to enhance energy storage usage and to optimize } \\
\text { existing utilities in the market. }\end{array}$ \\
\hline $\begin{array}{l}\text { Schallenberg \& } \\
\text { Haas (2012) }\end{array}$ & $\begin{array}{l}\text { Fixed FIT versus } \\
\text { premium in Spain }\end{array}$ & $\begin{array}{l}\text { Fixed-FIT policy should be used for those technologies } \\
\text { which have not achieved a high market penetration and } \\
\text { where it is required to build a market environment. }\end{array}$ \\
\hline $\begin{array}{l}\text { Proenca \& } \\
\text { Aubyn (2013) }\end{array}$ & $\begin{array}{l}\text { Effects of FIT to promote } \\
\text { renewable energy in } \\
\text { Portugal }\end{array}$ & $\begin{array}{l}\text { FIT policies provide an effective and cost-efficient } \\
\text { instrument to promote renewable energy sources for } \\
\text { electricity generation. Deployment of renewable energy led } \\
\text { to significant carbon emission reductions. }\end{array}$ \\
\hline $\begin{array}{l}\text { Jenner et al. } \\
\text { (2013) }\end{array}$ & $\begin{array}{l}\text { Assessing the strength } \\
\text { and effectiveness of FIT } \\
\text { in EU }\end{array}$ & $\begin{array}{l}\text { Combination of policy with electricity price and unit cost are } \\
\text { more important to serve as determinant for power generation } \\
\text { by renewable energy sources than a stand-alone policy } \\
\text { measure. }\end{array}$ \\
\hline
\end{tabular}


Table 2: Some empirical studies regarding tax incentive policies

\begin{tabular}{|c|c|c|}
\hline Author & Subject & Result \\
\hline $\begin{array}{l}\text { Kahn \& } \\
\text { Goldman (1987) }\end{array}$ & $\begin{array}{l}\text { Impact of tax reform on } \\
\text { renewable and } \\
\text { cogeneration project }\end{array}$ & $\begin{array}{l}\text { Capital intensive projects such as wind turbines, small } \\
\text { hydro, geothermal and wood-fired electricity were not } \\
\text { financially viable with the expiration of energy tax credits. } \\
\text { The avoided cost price is important to develop projects. }\end{array}$ \\
\hline Walsh(1989) & $\begin{array}{l}\text { Energy tax credit and } \\
\text { housing improvement }\end{array}$ & $\begin{array}{l}\text { Tax credits are not considered to be an effective solution to } \\
\text { subsidize energy conservation activities. It could be due to } \\
\text { the small discount rate, uncomfortable procedure to claim } \\
\text { the credit or lack of knowledge about price impact. }\end{array}$ \\
\hline $\begin{array}{l}\text { Alfsen et al. } \\
\text { (1995) }\end{array}$ & $\begin{array}{l}\text { Impacts of EC carbon tax } \\
\text { and deregulating power } \\
\text { supply on emissions }\end{array}$ & $\begin{array}{l}\text { Emissions are reduced by European Community (EC) tax by } \\
6 \text {-10 percent under both regimes (plan- and cost-efficient) } \\
\text { compared to the scenario without tax. }\end{array}$ \\
\hline $\begin{array}{l}\text { Hassett and } \\
\text { Metcalf (1995) }\end{array}$ & $\begin{array}{l}\text { Energy tax credits and } \\
\text { residential conservation }\end{array}$ & $\begin{array}{l}\text { They found that a } 10 \text { percentage point change in the rate of } \\
\text { tax incentive for energy investment could increase the } \\
\text { probability of investment by } 24 \text { percent. }\end{array}$ \\
\hline Kahn (1996) & $\begin{array}{l}\text { Production tax credit for } \\
\text { wind turbine power plants }\end{array}$ & $\begin{array}{l}\text { Production tax credit is considered an ineffective incentive } \\
\text { for wind turbine power plants, because it raises financing } \\
\text { costs. }\end{array}$ \\
\hline $\begin{array}{l}\text { Brännlund \& } \\
\text { Nordström } \\
(2004)\end{array}$ & $\begin{array}{l}\text { Carbon tax simulation } \\
\text { using a household model }\end{array}$ & $\begin{array}{l}\text { Households living in populated areas are influenced more } \\
\text { by } \mathrm{CO}_{2} \text { tax. Petrol demand will decrease by almost } 11 \\
\text { percent which affects carbon emissions. }\end{array}$ \\
\hline Barradale (2010) & $\begin{array}{l}\text { Wind power and the } \\
\text { production tax credit }\end{array}$ & $\begin{array}{l}\text { Wind power is not feasible in the lack of a production tax } \\
\text { credit. An incentive instrument applied for enhancing } \\
\text { renewable energy production may be changed to a } \\
\text { disincentive form if it comes with uncertainty. }\end{array}$ \\
\hline $\begin{array}{l}\text { Galinato \&Yodar } \\
\text { (2010) }\end{array}$ & $\begin{array}{l}\text { An integrated tax-subsidy } \\
\text { policy for carbon emission } \\
\text { reduction }\end{array}$ & $\begin{array}{l}\text { Revenues made by carbon taxes could be used to fund } \\
\text { subsidies for low-emitter fuels. Therefore, carbon tax and } \\
\text { subsidy mechanism is revenue neutral within the energy } \\
\text { industry. }\end{array}$ \\
\hline $\begin{array}{l}\text { Levin et al. } \\
\text { (2011) }\end{array}$ & $\begin{array}{l}\text { The role of renewable } \\
\text { electricity credits and } \\
\text { carbon taxes }\end{array}$ & $\begin{array}{l}\text { Low-cost biomass has the lowest levelized costs of } \\
\text { electricity in all scenarios. The importance of properly } \\
\text { designing policy in order to achieve targets has been } \\
\text { emphasized. }\end{array}$ \\
\hline $\begin{array}{l}\text { Pablo-Romero et } \\
\text { al. (2013) }\end{array}$ & $\begin{array}{l}\text { Incentives to promote solar } \\
\text { thermal energy in Spain }\end{array}$ & $\begin{array}{l}\text { Tax incentives have not had sufficient impacts on solar } \\
\text { thermal energy deployment due to regulatory change at the } \\
\text { national level which caused confusion within the system. }\end{array}$ \\
\hline Lehmann (2013) & $\begin{array}{l}\text { Supplementing and } \\
\text { emission tax by an FIT for } \\
\text { renewable electricity }\end{array}$ & $\begin{array}{l}\text { Optimal tax rate should be less than Pigouvian level, } \\
\text { differentiated across the fossil fuels, and modified } \\
\text { continuously based on technological change. }\end{array}$ \\
\hline
\end{tabular}


Table 3: Some empirical results regarding RPS policies

\begin{tabular}{|c|c|c|}
\hline Author & Subject & Result \\
\hline Espey (2001) & $\begin{array}{l}\text { RPS for trade with } \\
\text { electricity from } \\
\text { renewable energy } \\
\text { sources }\end{array}$ & $\begin{array}{l}\text { It cannot be considered a stand-alone solution for enhancing } \\
\text { renewable energy sources, but it is a good starting point for a } \\
\text { transition to an international trading system. }\end{array}$ \\
\hline $\begin{array}{l}\text { Berry \& Jaccard } \\
\text { (2001) }\end{array}$ & $\begin{array}{l}\text { Design consideration } \\
\text { and implementation of } \\
\text { RPS }\end{array}$ & $\begin{array}{l}\text { RPS system is managed by the government in Europe, but it is } \\
\text { administered by a delegation of governments and independent } \\
\text { utility regulators in the US and Australia. It is applied alongside } \\
\text { other support mechanisms. }\end{array}$ \\
\hline Lauber (2004) & $\begin{array}{l}\text { FIT and RPS options for } \\
\text { a harmonized } \\
\text { community framework }\end{array}$ & $\begin{array}{l}\text { The FIT mechanism is an appropriate policy to support } \\
\text { renewable technology development and the equipment industry, } \\
\text { while the RPS system is more suitable to the phase of near- } \\
\text { market competitiveness. }\end{array}$ \\
\hline $\begin{array}{l}\text { Wiser et al. } \\
\text { (2005) }\end{array}$ & $\begin{array}{l}\text { Evaluating experience } \\
\text { with renewable RPS in } \\
\text { US }\end{array}$ & $\begin{array}{l}\text { Some critical design pitfalls are as follows: narrow applicability, } \\
\text { poorly balanced supply-demand conditions, insufficient duration } \\
\text { and stability of targets, insufficient enforcement, and poorly } \\
\text { defined contracting standards and cost recovery mechanisms. }\end{array}$ \\
\hline $\begin{array}{l}\text { Nishio \& Asano } \\
\text { (2006) }\end{array}$ & $\begin{array}{l}\text { Supply amount and } \\
\text { marginal price of } \\
\text { renewable electricity } \\
\text { under the RPS in Japan }\end{array}$ & $\begin{array}{l}\text { Majority of power supplied under RPS are generated by wind and } \\
\text { biomass power. Purchase of certificates from generators in other } \\
\text { regions and trading among retailers enables the RPS system to be } \\
\text { implemented more effectively. }\end{array}$ \\
\hline Kydes (2007) & $\begin{array}{l}\text { Impacts of renewable } \\
\text { RPS on US energy } \\
\text { markets }\end{array}$ & $\begin{array}{l}\text { It will be effective to enhance renewable energy technologies } \\
\text { alongside an emission reduction of } \mathrm{NO}_{\mathrm{x}} \text { by } 6 \text { percent, mercury by } \\
4 \text { percent and } \mathrm{CO}_{2} \text { by } 16.5 \text { percent. }\end{array}$ \\
\hline Carley (2009) & $\begin{array}{l}\text { State renewable energy } \\
\text { electricity policy in the } \\
\text { US }\end{array}$ & $\begin{array}{l}\text { There is significant potential for RPS policies and an increase in } \\
\text { the percentage of states implementing this policy could lead to an } \\
\text { increase in RE deployment. Percentages of RE generation are } \\
\text { lower in deregulated states than regulated states. }\end{array}$ \\
\hline $\begin{array}{l}\text { Yin \& Powers } \\
\text { (2010) }\end{array}$ & $\begin{array}{l}\text { State RPS promote in- } \\
\text { state renewable } \\
\text { generation }\end{array}$ & $\begin{array}{l}\text { RPS policies have affected in-state renewable energy } \\
\text { development significantly. Also, allowing out-of-state certificate } \\
\text { trading has a negative impact on RPS deployment effectiveness. }\end{array}$ \\
\hline $\begin{array}{l}\text { Moon et al. } \\
\text { (2011) }\end{array}$ & $\begin{array}{l}\text { Economic analysis of } \\
\text { biomass power with } \\
\text { RPS in Korea }\end{array}$ & $\begin{array}{l}\text { Considering the current infrastructure and technology levels, } \\
\text { biomass gasification CHP ranging from } 0.5 \text { to } 5 \mathrm{MW}_{\mathrm{e}} \text { could be } \\
\text { considered as an ideal starting point to initiate the RPS } \\
\text { mechanism. }\end{array}$ \\
\hline Buckman (2011) & $\begin{array}{l}\text { The effectiveness of } \\
\text { RPS banding and carve- } \\
\text { outs in supporting } \\
\text { renewable energy }\end{array}$ & $\begin{array}{l}\text { Both methods have different strengths and weakness, but they } \\
\text { could enable markets to enhance renewable energy deployment. } \\
\text { Banding may be better than carve-outs to support high-cost } \\
\text { renewable energy technologies. }\end{array}$ \\
\hline Dong (2012) & $\begin{array}{l}\text { FIT vs. RPS: An } \\
\text { empirical test of their } \\
\text { relative effectiveness }\end{array}$ & $\begin{array}{l}\text { The FIT policy increased power capacity by } 1800 \mathrm{MW} \text { more than } \\
\text { the RPS mechanism. This capacity could increase to } 2000 \mathrm{MW} \\
\text { when the timing of the policy is taken into account due to the fact } \\
\text { that the FIT system started earlier than the RPS mechanism. }\end{array}$ \\
\hline $\begin{array}{l}\text { Fagiani et al. } \\
\text { (2013) }\end{array}$ & $\begin{array}{l}\text { Cost efficiency and } \\
\text { affectivity of renewable } \\
\text { energy support scheme }\end{array}$ & $\begin{array}{l}\text { FIT could achieve economic efficiency better than RPS, but it } \\
\text { depends on regulators' decisions. RPS has better performance } \\
\text { compared to FIT in terms of cost-efficiency when the degree of } \\
\text { risk aversion is moderate. }\end{array}$ \\
\hline
\end{tabular}

